\title{
Mortality, morbidity, and haematological results from a cohort of long term workers involved in 1,3-butadiene monomer production
}

\author{
Sally R Cowles, Shan P Tsai, Philip J Snyder, Charles E Ross
}

\begin{abstract}
A retrospective mortality analysis and prospective morbidity and haematological analyses were performed for Shell Deer Park Manufacturing Complex (DPMC) male employees who worked in jobs with potential exposure to 1,3-butadiene from 1948 to 1989.614 employees qualified for the mortality study (1948-89), 438 of those were still employed during the period of the morbidity study (1982-9), and 429 of those had haematological data available for analysis. Industrial hygiene data from 1979 to 1992 showed that most butadiene exposures did not exceed 10 ppm (eighthour time weighted average (8 hour TWA), and most were below 1 ppm, with an arithmetic mean of 3.5 ppm. 24 deaths occurred during the mortality study period. For all causes of death, the standardised mortality ratio (SMR) was $48(95 \%$ confidence interval $(95 \% \mathrm{CI})=$ 31-72), and the all cancer SMR was 34 (95\% CI = 9-87). There were only two deaths due to lung cancer (SMR 42, 95\% $\mathrm{CI}=5-151)$ and none due to lymphohaematopoietic cancer (expected $=1 \cdot 2$ ). Morbidity (illness absence) events of six days or more for the 438 butadiene employees were compared with the rest of the complex. No cause of morbidity was in excess for this group; the all cause standardised morbidity ratio (SMbR) was $85(95 \% \mathrm{CI}=77-93)$ and the all neoplasms SMbR was $51(95 \% \mathrm{CI}=22-100)$. Haematological results for the 429 with laboratory data were compared with results for the rest of the complex. No significant differences occurred between the two groups and the distributions of results between butadiene and non-butadiene groups were virtually identical. These results suggest that butadiene exposures at concentrations common at DPMC in the past 10-20 years do not pose a health hazard to employees.
\end{abstract}

(Occup Environ Med 1994;51:323-329)
Shell Oil Company, Corporate Medical Department, PO Box 2463, Houston, Texas 77252-2463, USA $S$ R Cowles S P Tsai P J Snyder C E Ross

Accepted 18 October 1993 butadiene toxicity both from the standpoint of employee and customer safety. Shell began producing butadiene in 1941 at the Shell Deer Park Refinery (later to become the Deer Park Manufacturing Complex (DPMC)). During the second world war, DPMC supplied up to one third of the nation's butadiene. ${ }^{1}$ Production of butadiene ceased in 1948 and was not resumed at Deer Park until 1970. Since 1970, the Deer Park facility has produced butadiene monomer without interruption.

Because of interest in the possible carcinogenicity of butadiene and because Shell is in the midst of an update of a mortality study of the entire DPMC originally conducted by Marsh et $a l,{ }^{2}$ we have been able to identify and evaluate the health experience of a cohort of employees with long term potential exposure to butadiene. Because many of these employees are still employed by Shell, it has been possible to examine not only their mortality, but also their morbidity (illness absence) and results of medical examinations. This report is divided into three parts. The first describes a retrospective mortality study of 614 employees from 1948 to 1989 . The second is an examination of the morbidity experience from 1982 to 1991 for those ( $\mathrm{n}=$ 438) still working during the period 1982 to 1989. The third is an evaluation of the haematological results from routine medical examination of employees $(n=429)$ with potential exposure to butadiene.

\section{Materials and methods}

PART I: MORTALITY STUDY

All male employees at DPMC with a minimum of five years of employment in jobs with potential exposure to butadiene or who worked at least one half of their total duration of employment in jobs with potential exposure to butadiene (with a three month minimum in such jobs) were eligible for the cohort. Seventy per cent of the cohort had five or more years in butadiene jobs. Women were excluded because only 35 met these criteria. Jobs included employees involved in butadiene production, maintenance personnel assigned to butadiene areas, butadiene laboratory staff, and shipping personnel involved in butadiene transfer and storage.

The Deer Park facility has been in operation since 1929 and includes refinery operations and several chemical production units. It currently handles substances such as oils, fuels, lubricants, benzene, 1,3-butadiene, iso- ene rubber, the rubber used for car and lorry tyres, among other products. As a producer of butadiene, Shell has an interest in potential
Shell Oil Company is a producer of 1,3-butadiene monomer (butadiene) that is sold to rubber industry producers who combine it 
propyl alcohol, epichlorohydrin, polynuclear aromatics, hydrogen sulphide, and epoxy resins. The purpose of this study design is intended to exclude employees whose work history at DPMC was predominantely spent in jobs with no potential exposure to butadiene. Some methodological issues of this type of design will be discussed later.

A total of 614 employees were identified who met these criteria. Vital status as of 31 December 1989 for each employee was determined from a number of sources including company records, the Social Security Administration's (SSA) master beneficiary record file, and the National Death Index (NDI). Those employees who stopped work after 31 December 1983 and who were not identified by the SSA or the NDI search were assumed to be alive. Death certificates were obtained for all of the decedents. For each death, the underlying cause of death was coded by trained nosologists according to the revision of the International Classification of Diseases in effect at the time of death.

A man who met the cohort criteria entered the study on 1 April 1948 if he had had at least five years of employment in jobs with potential exposure to butadiene before that date. Otherwise, he entered the study on the day he met the cohort eligibility criteria for employment in a butadiene job-that is, the day that an employee's potential exposure exceeds one half of the total duration of employment, or equals five years. Standardised mortality ratios (SMRs) adjusted for age, race, and calendar year were calculated based on Harris County, Texas (the county in which the DPMC is located) rates using the Occupational Cohort Mortality Analysis Program (OCMAP) from the University of Pittsburgh. ${ }^{3}$

PART II: MORBIDITY STUDY

The morbidity study population included 438 of the original 614 cohort members who were active at some time during the period 1 January 1982 to the end of December 1989. Morbidity data were extracted from the morbidity section of the Shell Health Surveillance System (HSS), which includes all illness absences in excess of five days. A detailed description of this database has been published elsewhere. ${ }^{4}$

A morbidity event in this study was defined as occurring when an employee had a specific diagnostic condition that resulted in an absence of more than five days during the 10 year period from 1982 to 1991. Only one morbidity event per employee was counted in any given diagnostic category during this period. If an employee had absences due to two different diagnostic categories during this period, two morbidity events (one for each diagnostic category) would be counted. The causes of morbidity were coded according to the International Classification of Diseases -9th revision clinical modification (ICD-9CM). ${ }^{5}$ The morbidity experience of this group was compared with that of an internal comparison group, defined as other male
DPMC employees active during the same period with potential plant exposures but with no exposure to butadiene.

Excesses and deficits of morbidity are expressed as standardised morbidity ratios (SMbRs) that were computed as the ratio of the observed to the expected morbidity events for each cause of interest. The expected numbers of morbidity events were calculated from the age, pay state (hourly or salaried), and cause specific morbidity of the internal comparison group. Tests of statistical significance were based on the assumption that the observed number of morbidity events follows a Poisson distribution. ${ }^{6}$

Selected health risk factors including smoking, raised blood pressure, raised cholesterol, and obesity were also examined to evaluate the differences in health habits between the butadiene group and the internal comparison group. The employee's smoking history was used to determine whether the employee was a current cigarette smoker. Raised cholesterol was defined as a value equal to or greater than $200 \mathrm{mg} / \mathrm{dl}(5 \cdot 18 \mathrm{mmol} / \mathrm{l})$. Raised blood pressures were those diastolic blood pressure readings equal to or greater than $90 \mathrm{~mm} \mathrm{Hg}(11.97 \mathrm{kPa})$ or systolic blood pressure readings equal to or greater than $140 \mathrm{~mm} \mathrm{Hg}(18.62 \mathrm{kPa})$. Obesity was defined as body mass index $(B M I=$ weight (kg)/height $(\mathrm{m})^{2}$ ) greater than or equal to $27 \cdot 2$. This value represents $20 \%$ more than ideal body weight. ${ }^{7}$

\section{PART III: HAEMATOLOGICAL DATA} EVALUATION

Four hundred and twenty nine of the 438 employees included in the morbidity study had haematological data from periodic physical examinations provided by the company. The most current laboratory test results were used and compared with similar results for over 2600 non-exposed DPMC employees. About $80 \%$ of these tests were done between 1985 and 1991. Seven haematological outcomes including red cell count $\left(10^{6} / \mathrm{mm}^{3}\right)$, haemoglobin concentration $(\mathrm{g} / 100 \mathrm{ml})$, mean corpuscular volume $\left(\mu \mathrm{m}^{3}\right)$, platelet count $\left(10^{3} / \mathrm{mm}^{3}\right)$, white blood cell count $\left(10^{3} / \mathrm{mm}^{3}\right)$, neutrophil count $\left(10^{3} / \mathrm{mm}^{3}\right)$, and lymphocyte count $\left(10^{3} / \mathrm{mm}^{3}\right)$ were examined. Mean values of each of these variables (except platelet count), adjusted for the effects of age and smoking state (current smoker or nonsmoker), were computed by a convariance method. ${ }^{8}$

\section{Results}

PART I: MORTALITY

A total of 614 DPMC employees who satisfied the cohort criteria contributed 7232 person-years to the SMR determinations. Black employees accounted for only $11 \%$ of the study cohort. The average age at entry into the cohort was 31 years and the average follow up was 15 years (range less than 1 to 42 years). Duration of employment in jobs with potential exposure to butadiene ranged 
from less than 1 to 20 years and averaged $7 \cdot 6$ years. One third of the cohort members were hired before 1970. Seventy three per cent of the cohort had had a minimum of five years in jobs with potential exposure to butadiene; more than half $(59 \%)$ of them were hired since 1970 . The remaining $27 \%(n=163)$ of the cohort did not meet the five year potential exposure criterion, but one half of their total duration of employment was in jobs with potential exposure to butadiene $(2.5$ years average duration of employment and 1.7 years of potential exposure); $82 \%$ of this group was hired in 1970 or later. Table 1 shows the vital and employment status distribution of the cohort on 31 December 1989. Follow up was almost $100 \%$. A total of 589 employees were still alive and $53 \%$ of the

Table 1 Distribution of vital status (as of 31 December 1989) of the mortality study population

\begin{tabular}{lcr}
\hline Vital status & Number & $\%$ \\
\hline Currently employed & 327 & 53.3 \\
Terminated & 162 & 26.4 \\
$\quad$ Alive & 158 & 97.5 \\
Dead & 3 & 1.9 \\
Unknown & 1 & 0.6 \\
Retired & 112 & $18 \cdot 2$ \\
Alive & 104 & 92.9 \\
Dead & 8 & $7 \cdot 1$ \\
Died while employed & 13 & 2.1 \\
Total & 614 & 100.0 \\
\hline
\end{tabular}

Table 2 Cohort statistics for the morbidity study population

\begin{tabular}{llc}
\hline Characteristics & $\begin{array}{l}\text { Butadiene } \\
\text { cohort }\end{array}$ & $\begin{array}{l}\text { Internal } \\
\text { comparison }\end{array}$ \\
\hline $\begin{array}{l}\text { Number studied } \\
\text { Number of person-years, } \\
\text { observed }\end{array}$ & 438 & 2,703 \\
$\begin{array}{l}\text { Average age at entry } \\
\text { Average total duration } \\
\text { of employment (y) }\end{array}$ & 3305 & 18385 \\
$\begin{array}{l}\text { Average duration of } \\
\text { potential exposure to }\end{array}$ & $19 \cdot 3$ & $40 \cdot 6$ \\
$\begin{array}{l}\text { butadiene (y) } \\
\text { Hired pre-1970 }\end{array}$ & $9 \cdot 1 \cdot 1(32 \cdot 4 \%)$ & $1082(40 \cdot 0 \%)$ \\
\begin{tabular}{l} 
Hired post-1970 \\
\hline
\end{tabular} & $296(67 \cdot 6 \%)$ & $1621(60 \cdot 0 \%)$ \\
\hline
\end{tabular}

Table 3 Number of observed (OBS) and expected (EXP) morbidity and standardised morbidity ratios (SMbRs) according to cause

\begin{tabular}{|c|c|c|c|}
\hline $\begin{array}{l}\text { Cause of morbidity } \\
\text { (ICD-CM 9th revision codes) }\end{array}$ & Obs & $\operatorname{Exp}$ & $S M b R(95 \% C I)$ \\
\hline All causes $(000-999)$ & 473 & $556 \cdot 8$ & $85 \cdot 0(77 \cdot 5-93 \cdot 1)$ \\
\hline \multicolumn{4}{|l|}{ Infective and parasitic diseases } \\
\hline All neoplasms (140-239) & $\begin{array}{r}13 \\
8\end{array}$ & $\begin{array}{l}15 \cdot 6 \\
15 \cdot 7\end{array}$ & $\begin{array}{l}83.2(44.3-142 \cdot 3) \\
50.9(21.9-100 \cdot 3)\end{array}$ \\
\hline \multicolumn{4}{|l|}{ Endocrine, nutritional, and metabolic } \\
\hline diseases $(240-279)$ & 9 & 8.9 & $101 \cdot 0(46 \cdot 1-191 \cdot 8)$ \\
\hline Mental disorders (290-319) & 10 & $20 \cdot 1$ & $49.7(23.8-91.4)$ \\
\hline Nervous system $(320-389)$ & 28 & $28 \cdot 5$ & $98 \cdot 3(65 \cdot 3-142 \cdot 1)$ \\
\hline Heart disease $(390-414,420-429)$ & 18 & $29 \cdot 9$ & $60 \cdot 2(35.6-95.1)$ \\
\hline Cerebrovascular disease $(430-438)$ & 0 & $1 \cdot 3$ & - \\
\hline \multirow{2}{*}{\multicolumn{4}{|c|}{$\begin{array}{l}\text { Diseases of other circulatory systems } \\
(440-448,451-459)\end{array}$}} \\
\hline & 13 & 13.7 & $95 \cdot 1(50 \cdot 6-162 \cdot 6)$ \\
\hline Respiratory system $(460-519)$ & 84 & $81 \cdot 2$ & $103 \cdot 5(82 \cdot 5-128 \cdot 1)$ \\
\hline Digestive system $(520-579)$ & 39 & $56 \cdot 1$ & $69.5(49.2-95.0)$ \\
\hline Genitourinary system $(580-629)$ & 16 & 21.9 & $73 \cdot 1(41 \cdot 8-118 \cdot 8)$ \\
\hline \multicolumn{4}{|l|}{$\begin{array}{l}\text { Skin and subcutaneous tissue } \\
(680-709)\end{array}$} \\
\hline$(680-709)$ & 13 & 15.9 & $81.5(43.4-139.4)$ \\
\hline Musculoskeletal system (710-739) & 58 & $73 \cdot 1$ & $79 \cdot 3(60 \cdot 2-102 \cdot 5)$ \\
\hline \multicolumn{4}{|l|}{ Symptoms and ill defined conditions } \\
\hline$(780-799)$ & 73 & $72 \cdot 5$ & $100 \cdot 6(78 \cdot 9-126 \cdot 6)$ \\
\hline Injury and poisoning $(800-999)$ & 91 & $100 \cdot 8$ & $90 \cdot 3(72 \cdot 7-110 \cdot 8)$ \\
\hline All other causes & 0 & $1 \cdot 6$ & - \\
\hline
\end{tabular}

cohort members were still working at the end of the study period. Twenty four deaths were identified and death certificates were obtained for all of the decedents. One half of the 24 deaths occurred in cohort members hired before 1949 .

The SMR for all causes combined was $52 \%$ lower than expected when compared with the local country rates (SMR 48, 95\% confidence interval $(95 \% \mathrm{CI}=31-72))$. The mortality for all malignant neoplasms was also significantly lower (SMR 34, 95\% CI = 9-87), based on four observed deaths. There were no deaths due to cancer of the lymphatic and haematopoietic tissue in the group ( 1.2 expected), and only two deaths from lung cancer (SMR 42, 95\% CI = 5-151). There were eight deaths due to heart disease (SMR 51, 95\% CI = 22-101). Mortality from non-malignant respiratory disease was $20 \%$ lower than expected (SMR 80, 95\% $\mathrm{CI}=10-290)$. Because of the small number of deaths from any specific cause, the statistical findings are unstable as illustrated by the wide range of $95 \%$ CIs. For type I error $(\alpha)=$ 0.05 and type II error $(\beta)=0.20$, the study size and duration is sufficient to detect a fivefold excess in lymphohaematopoietic cancer if it were present.

PART II: MORBIDITY

Table 2 presents the characteristics of the 438 butadiene employees for whom illness absence data were available compared with the 2703 employees with no employment in jobs with potential exposure to butadiene. Age at entry and duration of employment were similar for both groups. The butadiene cohort had an average of 9.1 years in jobs involving butadiene. It is noteworthy that the average duration of employment for the internal comparison group was 1.3 years longer than the butadiene cohort (20.6 years $v 19.3$ years).

Table 3 summarises the SMbRs by cause of morbidity for the butadiene employees. Shell butadiene employees had rates equal to or lower than the rest of the DPMC population. In particular, absences due to cancers were especially low (SMbR 51;95\% CI = 22-100), as were those due to heart disease (SMbR 60;95\% CI = 36-95). All causes of morbidity combined in the butadiene group were also significantly lower than the comparison group (SMbR 85; 95\% CI $=78-93$ ). There was one observed illness absence and 0.8 expected due to a lymphohaematopoietic neoplasm in the butadiene group, a non-

Table 4 Age and pay state adjusted prevalence rates * for selected disease risk factors (morbidity cohort)

\begin{tabular}{llll}
\hline Risk factors & $\begin{array}{l}\text { Butadiene } \\
\text { Cohorn }\end{array}$ & $\begin{array}{l}\text { Internal } \\
\text { Comparison }\end{array}$ & $p$ Value \\
\hline Smoking & 24.3 & 28.3 & 0.09 \\
High blood pressure & 25.6 & $29 \cdot 2$ & 0.22 \\
Hypercholesterolaemia & 62.0 & 57.6 & 0.18 \\
Obesity & 55.7 & 49.3 & 0.06 \\
\hline
\end{tabular}

^Per 100 employees. Age and pay state adjusted to the internal comparison population by the direct standardisation nal com 
Table 5 Frequency distribution of the most recent haematology data for the butadiene cohort

\begin{tabular}{|c|c|c|}
\hline & $\begin{array}{l}\text { Butadiene } \\
\text { cohort } \\
\text { No (\%) }\end{array}$ & $\begin{array}{l}\text { Internal } \\
\text { comparison } \\
\text { No }(\%)\end{array}$ \\
\hline $\begin{array}{l}\text { White blood cells: } \\
<4000 / \mathrm{mm}^{3} \\
4000-12000 / \mathrm{mm}^{3} \\
>12000 / \mathrm{mm}^{3} \\
\text { Total }\end{array}$ & $\begin{array}{rr}8 & (1 \cdot 9) \\
417 & (97 \cdot 2) \\
4 & (0 \cdot 9) \\
429 & (100 \cdot 0)\end{array}$ & $\begin{array}{rr}93 & (3 \cdot 5) \\
2478 & (94 \cdot 4) \\
54 & (2 \cdot 1) \\
2625 & (100 \cdot 0)\end{array}$ \\
\hline $\begin{array}{l}\text { Haemoglobin: } \\
<13.0 \mathrm{~g} / 100 \mathrm{ml} \\
>13.0 \mathrm{~g} / 100 \mathrm{ml} \\
\text { Total }\end{array}$ & $\begin{array}{rr}3 & (0 \cdot 7) \\
426 & (99 \cdot 3) \\
429 & (100 \cdot 0)\end{array}$ & $\begin{array}{rr}23 & (0.9) \\
260 & (99 \cdot 1) \\
2623 & (100 \cdot 0)\end{array}$ \\
\hline $\begin{array}{l}\text { Platelets: } \\
<140000 / \mathrm{mm}^{3} \\
>140000 / \mathrm{mm}^{3} \\
\text { Total }\end{array}$ & $\begin{array}{rr}4 & (0.9) \\
423 & (99 \cdot 1) \\
427 & (100.0)\end{array}$ & $\begin{array}{rr}20 & (0 \cdot 8) \\
2582 & (99 \cdot 2) \\
2602 & (100 \cdot 0)\end{array}$ \\
\hline $\begin{array}{l}\text { Mean corpuscular volume: } \\
>100 \mu \mathrm{m}^{3} \\
<100 \mu \mathrm{m}^{3} \\
\text { Total }\end{array}$ & $\begin{array}{rr}8 & (1 \cdot 9) \\
418 & (98 \cdot 1) \\
426 & (100 \cdot 0)\end{array}$ & $\begin{array}{rr}69 & (2 \cdot 6) \\
2542 & (97 \cdot 4) \\
2611 & (100 \cdot 0)\end{array}$ \\
\hline
\end{tabular}
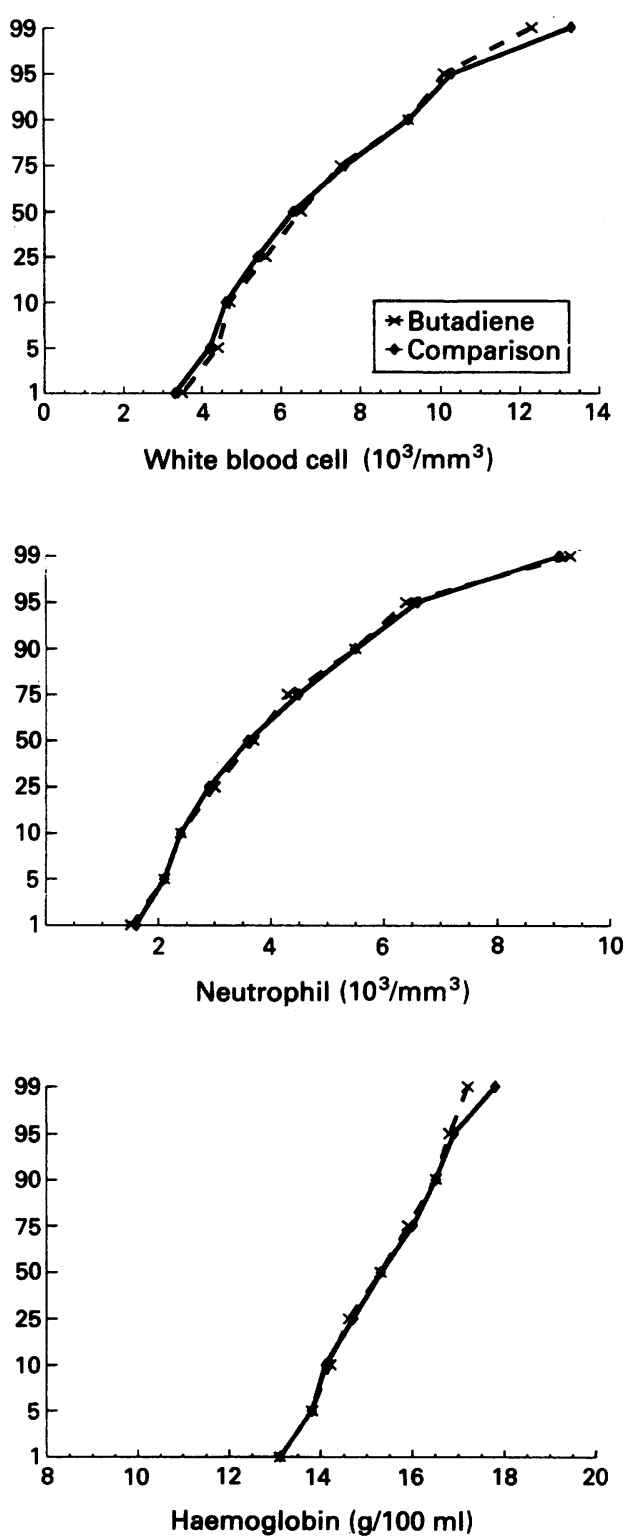

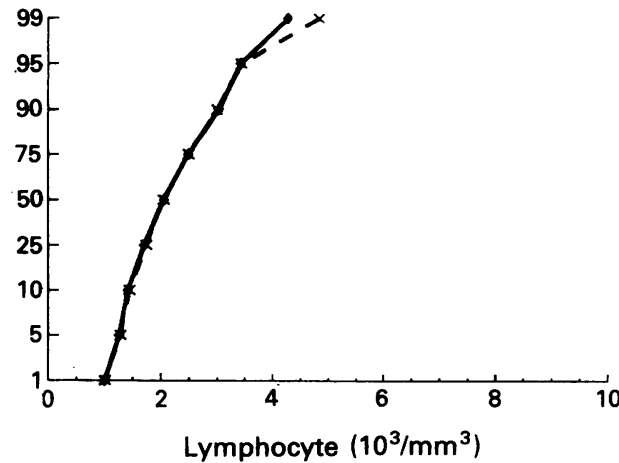

Hodgkin's lymphoma (ICD code 202). This man was hired in 1970 at DPMC and worked for a total of seven years in butadiene jobs from 1971-7 and between 1980-1. Most of this employee's work history at DPMC has been spent in jobs with no exposure to butadiene. He was diagnosed with lymphoma in 1989 , and is still alive and an active employee at DPMC.

Table 4 summarises the relative frequencies of certain cardiovascular risk factors in the two groups. No differences were statistically significant, but workers in the butadiene group were somewhat less likely to smoke or to have high blood pressure. On the other hand, these workers were somewhat more likely to be obese and to have a serum cholesterol over $200 \mathrm{mg} / \mathrm{dl}(5 \cdot 18 \mathrm{mmol} / \mathrm{l})$.

PART III: HAEMATOLOGICAL DATA

Tables 5 and 6 provide frequency distribution and mean data, respectively, for the haematological variables studied. The figure
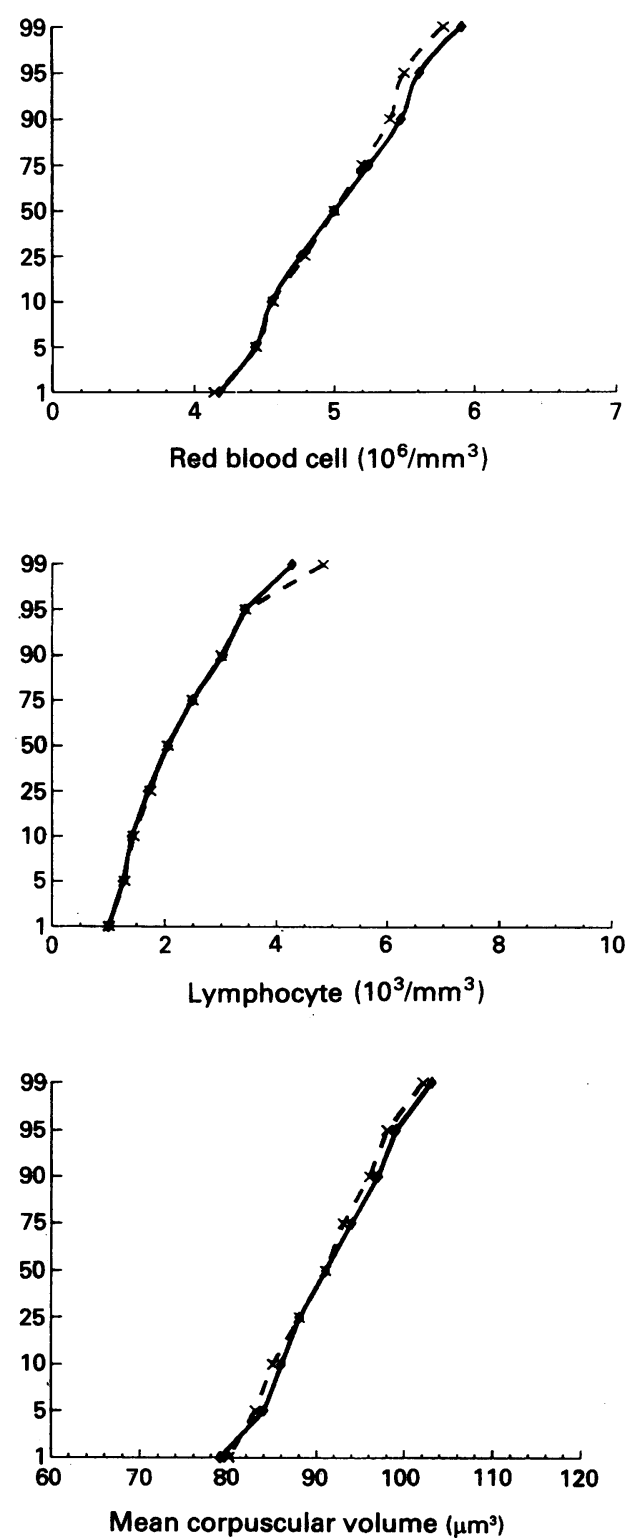

Figure Cumulative frequency distribution for selected haematological data. 
Table 6 Comparisons of adjusted mean haematological variable values between butadiene cohort and the internal comparison group

\begin{tabular}{lccc}
\hline Variable & $\begin{array}{c}\text { Butadiene cohort } \\
(n=402)\end{array}$ & $\begin{array}{c}\text { Internal comparison } \\
(n=2460)\end{array}$ & $p$ Value \\
\hline Red blood cells $\left(10^{\circ} / \mathrm{mm}^{3}\right)$ & $5 \cdot 009$ & $5 \cdot 010$ & $0 \cdot 98$ \\
Haemoglobin $\left(\mathrm{g} / 100 \mathrm{ml}^{2}\right)$ & $15 \cdot 4$ & $15 \cdot 4$ & $0 \cdot 76$ \\
Mean corpuscular volume $\left(\mu / \mathrm{mm}^{3}\right)$ & $91 \cdot 3$ & $91 \cdot 5$ & $0 \cdot 36$ \\
White blood cells $\left(10^{3} / \mathrm{mm}^{3}\right)$ & $7 \cdot 091$ & $7 \cdot 022$ & $0 \cdot 49$ \\
Neutrophils $\left(10^{3} / \mathrm{mm}^{3}\right)$ & $4 \cdot 143$ & $4 \cdot 127$ & $0 \cdot 83$ \\
Lymphocytes $\left(10^{3} / \mathrm{mm}^{3}\right)$ & $2 \cdot 247$ & $2 \cdot 232$ & 0.67 \\
\hline
\end{tabular}

*Adusted for age and smoking state. Persons with missing age or smoking data are excluded from the analysis.
Table 7 Comparisons of adjusted ${ }^{\star}$ mean haematological variable values between butadiene shipping subgroup and other butadiene employees

\begin{tabular}{lccc}
\hline Variable & $\begin{array}{l}\text { Butadiene shipping } \\
(n=36)\end{array}$ & $\begin{array}{l}\text { Other Butadiene } \\
(n=366)\end{array}$ & p Value \\
\hline Red blood cells $\left(10^{6} / \mathrm{mm}^{3}\right)$ & $5 \cdot 020$ & $5 \cdot 000$ & 0.73 \\
Haemoglobin $(\mathrm{g} / 100 \mathrm{ml})$ & 15.5 & $15 \cdot 4$ & 0.47 \\
Mean corpuscular volume $\left(\mu \mathrm{m}^{3}\right)$ & $91 \cdot 4$ & 91.3 & 0.83 \\
White blood cells $\left(10^{3} / \mathrm{mm}\right)$ & $7 \cdot 159$ & $7 \cdot 012$ & 0.61 \\
Neutrophils $\left(10^{3} / \mathrm{mm}^{3}\right)$ & $4 \cdot 160$ & $4 \cdot 079$ & $0 \cdot 73$ \\
Lymphocytes $\left(10^{3} / \mathrm{mm}^{3}\right)$ & $2 \cdot 257$ & $2 \cdot 243$ & 0.90 \\
\hline
\end{tabular}

*Adjusted for age and smoking state. Persons with missing age or smoking data are excluded from the analysis. ity and morbidity experience. Also, and perhaps most importantly for the current workforce, there were no differences in haematology test results between butadiene employees and the internal comparison group of equivalent age and with equivalent or slightly longer duration of employment at DPMC. Recent potential butadiene exposures (1979-92) in butadiene jobs have been measured to range from less than $0.1 \mathrm{ppm}$ to $143 \mathrm{ppm}$ on an eight hour TWA basis. Most were below $1 \mathrm{ppm}$ with an arithmetic mean of $3.5 \mathrm{ppm}$.

Consistent with industrial practice in the United States, employee hiring practices at DPMC during the study period included a preplacement medical examination. No specific screening was provided for employment in butadiene job assignments within the plant. The extremely favourable mortality, for all causes and heart disease, of this cohort is probably due to a combination of factors such as the healthy worker effect, the relative absence of risks related to employment, and the beneficial effects of continuing employment. ${ }^{9-12}$ As over half of the cohort members were hired in 1970 or later with an average follow up of 12 years; they were relatively young. The average age at close of follow up was 46 years; $53 \%$ of the cohort members were still working. It has been shown that a strong healthy worker effect may exist under these cohort characteristics. ${ }^{9-13}$

In the mortality analysis restricted to employees with definite opportunity for exposure to butadiene there were no deaths from leukaemia or other lymphohaematopoietic neoplasm. If the risks described in the casecontrol study of Santos-Burgoa et al ${ }^{14}$ were present at DPMC, the number of deaths from lymphohaematopoietic cancer should be greater than five and the probability of observing no such deaths would be less than $0 \cdot 05$. Leukaemias ${ }^{1415}$ and lymphosarcomas ${ }^{16}$ have been reported to be in excess in some subgroups of short term styrene-butadiene rubber and 1,3-butadiene monomer workers. It has, however, been noted that even in those studies, the longer term employees in the industry were not affected, which questions the relevance of such associations to exposure to butadiene. ${ }^{16-18}$

The small population size and small number of deaths in the DPMC butadiene group result in unstable rates as reflected by the wide confidence intervals; however no evidence of any association between exposures to butadiene and cancer is seen in this study. On the contrary, a very strong healthy worker effect is present. More importantly, the illness-absence experience and ongoing haematological test results also show no evidence for any adverse health effects as a result of exposure to butadiene at concentrations found at DPMC. For these two morbidity analyses, the internal comparison of employees at the same location was used. No potential bias is associated with the healthy worker effect in this type of study design. In an earlier morbidity study, DPMC employees as
The employees of Shell DPMC who worked in butadiene jobs showed favourable mortal- 
a whole were found to have slightly higher morbidity than the entire Shell Manufacturing employee population. ${ }^{19}$ By contrast, the butadiene employee group at DPMC shows rates equal to or lower than the rest of DPMC for any cause of morbidity. It is unlikely that the slightly lower overall smoking rates in the butadiene group account for the lower morbidity seen, but smoking has been shown to be a major contributing factor to morbidity in the Shell employee population. ${ }^{20}$

The haematological test results for the butadiene employees showed no significant differences from those for the rest of DPMC, and showed no evidence for any exposure related effects on the haematological system. This is similar to results reported by Checkoway et al, ${ }^{21}$ which showed no evidence of any butadiene related haematological abnormality. The study of Checkoway et al found no significant mean differences in a single subgroup of eight workers with higher exposure to butadiene. ${ }^{21}$

When the Shell subgroup of 36 employees with at least one year of employment in a butadiene shipping job, (jobs with the highest potential exposure to 1,3-butadiene) was compared with the rest of the butadiene cohort, no mean differences were found. The shipping subgroup was chosen because job duties and exposures are similar to the eight tank farm workers evaluated by Checkoway et $a l .{ }^{21}$ Our findings confirm the lack of exposure related haematological effects in a somewhat larger population than that studied by Checkoway et al.

The haematological results are especially pertinent to current employees at current exposure concentrations. Not even subtle variations in mean haematological variables were found. The importance of this finding is that without evidence for bone marrow injury from exposure, it is difficult to postulate an association between exposure and later leukaemia, should it develop. This is by contrast with the Pliofilm workers exposed to benzene who clearly showed early evidence of marrow depression. ${ }^{22}$

The morbidity analysis, because it considered morbidity events between 1982 and 1991 is primarily a study of employees with potential exposures to butadiene after 1970 . Such analyses are likely to be more pertinent to current exposure to butadiene in industry than exposures experienced by employees during the second world war. The one case of illness absence due to lymphoma in the DPMC butadiene cohort does not represent an excess, and occurred in an employee with only seven of his 23 years to date with Shell spent in jobs with potential for exposure to butadiene.

The butadiene group in this study excluded employees whose career at DPMC was predominantely spent in jobs with no potential for exposure to butadiene. Longer term employees, who accounted for $73 \%$ of the cohort, had to have worked five years in jobs with potential for exposure to butadiene.
Given the many potential chemical exposures in this petrochemical complex, such criteria are considered important in sorting out potential exposure related effects. Unfortunately, because butadiene operations ceased in late 1948 and did not resume again at DPMC until 1970, not all of the early butadiene production workforce were included in the mortality analysis. Shorter term employees $(9 \%$ of the cohort) with recent hire dates-for example, after 1980-might be more likely to satisfy the cohort entry criteria provided their entry job was in a butadiene area. Also, employees who were hired after 1948 but before 1965 and who worked less than five years in a butadiene job are preferentially excluded because less than one half their total employment is likely to have been in a butadiene exposure job.

A potential problem with this type of study design is that the inclusion of an employee into the study is time dependent. For example, some short term employees whose first job was in a butadiene unit or persons with very recent hire dates might be more likely to satisfy the inclusion criterion. Since this inclusion criterion is a function of duration of employment and duration of exposure, the cohort could include someone who had worked in the plant for four months potentially exposed throughout, but exclude a worker employed for 10 years but potentially exposed for four years. On the other hand, this cohort may be more fairly characterised as butadiene workers because a major proportion of member employment years were associated with potential butadiene exposure. Employees excluded by this approach could in fact be best described as being vinyl chloride monomer, epichlorohydrin, benzene, or other petrochemical workers.

To evaluate the potential impact introduced by the use of the entry criteria involving two different durations of exposure, we have selected a group of employees with a single eligibility criterion-namely, employment in potential butadiene exposed jobs for at least three years. This minimises censoring in the early production period and yet eliminates short term employees with short term employment in butadiene jobs. A total of 642 employees were identified; $42 \%$ of them were hired before 1970. The average duration of employment for this group was 20 years with an average of eight years in butadiene jobs Thirty one deaths were identified, and death certificates were obtained for 30 decedents. Fifty five per cent of the 31 decedents occurred in cohort members hired in 1948 or earlier. The SMR for overall causes was 47 $(95 \% \mathrm{CI}=32-67)$. Six cancer deaths were found with an SMR of $36(95 \% \mathrm{CI}=13-79)$. There were no deaths due to cancer of the lymphatic and haematopoietic tissue in this group ( 1.5 expected). The SMR for heart disease was low with 13 observed deaths (SMR $=58,95 \% \mathrm{CI}=31-99)$. These results are virtually the same as the ones based on the original definition of the cohort.

There were 530 persons still working 
during the period from 1 January 1982 to 31 December 1989. Their morbidity experience was compared with the rest of the DPMC employees who had at least three years of employment. The morbidity results of this analysis were similar to those presented in table 3, although the age adjusted morbidity ratio for all causes was higher (696 observed, SMbR 93; 95\% CI = 87-101). The morbidity ratio for cancer was also higher with an $\mathrm{SMbR}$ of 67 (14 observed, $95 \% \mathrm{CI}=$ 36-112). The patterns of excesses and deficits for the remaining causes were not altered. For example, the morbidity for heart disease was low with an SMbR of 83 (95\% $\mathrm{CI}=56-117$ ); diseases of the respiratory system increased slightly as with the previous analysis (SMbR 109; 95\% CI = 90-130); and the $\mathrm{SMbR}$ for injury was $94(95 \% \mathrm{CI}=$ 78-112).

The strength of this study is that a comprehensive examination of a long term group of employees potentially exposed to butadiene has been performed that has included not only mortality, but also morbidity and laboratory examination results. This group shows no evidence for any adverse health effects from either past or current butadiene exposures in Shell butadiene monomer production operations. We conclude from these analyses that butadiene exposures found at DPMC since 1970 are unlikely to pose a risk to the health of employees.

We thank Dr Philip Cole, Dr Otto Wong, Dr Manolis Kogevinas, and Dr Gerald Ott for their helpful comments.

1 Wells B. Shell at Deer Park, The story of the first fifty years. Houston, Texas: Shell Oil Company, 1979.

2 Marsh GM, Enterline PE, McCraw D. Mortality patterns among petroleum refinery and chemical plant workers. Am f Ind Med 1991;19:29-42.
3 Marsh GM, Ehland J, Paik M, Preininger ME, Caplan R. OCMAP/PC:A: User-oriented cohort mortality analysis program for the IBM PC. Am Statistics 1986;40:308-9.

4 Joyner RE, Pack PH. The Shell Oil Company's computerised health surveillance system. $\mathcal{F}$ Occup Med 1982; 24:812-14.

5 Commission on Professional and Hospital Activities. International Classifications of Disease, 9th Revision, Clinical Modification. Ann Arbor, Michigan: CPHA, 1978.

6 Bailar JC, Ederer F. Significance factors for the ratio of a Poisson variable to its expectation. Biometrics 1964;20: 639-42.

7 National Institutes of Health consensus development panel on the health implications of obesity. National Institute of Health consensus development conference statement. Ann Intern Med 1985;103:1073-7.

8 Kleinbaum DG, Kupper LL. Applied regression analysis and other multivariate methods. North Scituate, Massachusetts: Duxburg Press, 1978.

9 Fox Aj, Collier PF. Low mortality rates in industrial cohort studies due to selection for work and survival in the industry. Br 7 Prev Soc Med 1976;30:225-30.

10 Ott MG, Holder BB, Langner RR. Determinants of mortality in an industrial population. $f$ Occup Med 1976; 18:171-7.

11 Wen CP, Tsai SP, Gibson RL. Anatomy of the healthy worker effect. $\mathcal{F}$ Occup Med 1986;28:425-33.

12 Monson RR. Observations on the healthy worker effect. $f$ Occup Med 1986;28:425-33.

13 Wen CP, Tsai SP, Weiss NS, Gibson RL. Long-term mortality of oil refinery workers: V. Comparison of workers hired before, during, and after World War II (1940-1945) with a discussion of the impact of study designs on cohort results. Am $\mathcal{F}$ Ind Med 1986;9:171-80.

14 Santos-Burgoa C, Matanoski GM, Zeger S, Schwartz L. Lymphohaematopoietic cancer in styrene-butadiene polymerization workers. Am f Epidemiol 1992;136: 843-54.

15 Meinhardt TJ, Lemen RA, Crandall MS, Young RJ. Environmental epidemiologic investigation of the styrene-butadiene rubber industry. Scand $f$ Work Environ Health 1991;8:250-9.

16 Divine BJ. An update on mortality among workers at a 1,3-butadiene facility-preliminary results. Environ 1,3-butadiene facility-preliminar

17 Acquavella JF. The paradox or butadiene epidemiology. Experimental Pathology 1989;36:114-8.

18 Cole P, Delzell E, Acquavella J. Exposure to butadiene and lymphatic and haematopoietic cancer. Epidemiology 1993;4:96-103.

19 Tsai SP, Dowd CM, Cowles SR, Ross CE. A prospective study of morbidity patterns in a petroleum refinery and chemical plant. Br f Ind Med 1992;49:516-22.

20 Tsai SP, Cowles SR, Ross CE. Smoking and morbidity frequency in a working population. If Occup Med 1990;32:245-9.

21 Checkoway H, Williams TM. A haematology survey of workers at a styrene-butadiene synthetic rubber manuworkers at a styrene-butadiene synthetic rubber mant

22 Kipen HM, Cody RP, Goldstein BD: Use of longitudina analysis of peripheral blood counts to validate historical analysis of peripheral blood counts to validate historical reconstruction of benzen
Perspect 1989;82:199-206. 